\title{
STUDY OF THE INFLUENCE OF FIBRES TYPE AND DOSAGE ON PROPERTIES OF CONCRETE FOR AIRPORT PAVEMENTS
}

Mihai DICU, PhD, Prof. Eng., Faculty of Railways, Roads and Bridges, Technical University of Civil Engineering Bucharest, e-mail: mihaidicu05@gmail.com

Andreea MATEI, Eng., Transport Infrastructure Engineering Master Program, Faculty of Railways, Roads and Bridges, Technical University of Civil Engineering Bucharest, e-mail: andreeamatei09@gmail.com

Constantin Dorinel VOINIT,CHI, PhD, Prof. Eng., Faculty of Railways, Roads and Bridges, Technical University of Civil Engineering Bucharest, e-mail: voinitchi65@yahoo.com

\section{Rezumat}

Lucrarea urmărește implicatiile utilizării betoanelor de ciment armate cu fibre, ca soluție aplicabilă pistelor aeroportuare, cu scopul creșterii rezistentei la incovoiere și, in consecinţă, scăderea grosimilor dalelor utilizate în mod curent la construcția aeroporturilor.

Experimental, s-au studiat proprietațile betoanelor rutiere armate cu 3 procente diferite de fibră $(0,5 \%, 1 \%$ și $1,5 \%$ din volumul de beton) dar și cu 4 tipuri diferite de fibre (pentru procentul de armare de $1 \%$ - fibră metalică cu ciocuri $-50 \mathrm{~mm}$, fibră metalică cu ciocuri - 30 mm, fibră metalică ondulată - 30mm, fibră de polipropilenă $-50 \mathrm{~mm}$ ), plecând de la o rețetă de beton rutier BcR 5 .

Mai exact, studiul prezinta variatia rezistențelor la compresiune si încovoiere, contracțiilor, coeficientului de dilatare, modulului de elasticitate și coeficientului lui Poisson, funcție de tipul si dozajul de fibră.

Pentru betonul cu cele mai mari performanțe obținut experimental (rezistența caracteristică la încovoiere $7 \mathrm{MPa}$ ) s-a efectuat dimensionarea structurii rutiere a pistei prin metoda generală și metoda optimizată și evaluarea capacității portante prin metoda ACN PCN, prin comparație cu un beton rutier uzual (BcR 5). De asemenea s-a subliniat posibilitatea scăderii grosimii dalelor proporțional cu creșterea clasei de beton prin calculul structurilor prin două metode de dimensionare cu un beton de înaltă performanță (BcR 9).

Cuvinte cheie: beton, rutier, fibră, pistă, dimensionare

\section{Abstract}

The paper follows the potential practice of fiber reinforced concrete (FRC) as a solution for airport's runway pavements, in order to increase the bearing strength, resulting in decreasing the height of the concrete layer that is currently used.

Experimentally, the study focuses on the properties of fiber reinforced Portland cement concrete using 3 different percentages $(0.5 \%, 1 \%$ and $1.5 \%$ of the concrete volume) and 4 different types of fiber (for $1 \%$ percentage - hooked steel fiber $50 \mathrm{~mm}$ length, hooked 
steel fiber $30 \mathrm{~mm}$ length, crimped steel fiber $30 \mathrm{~mm}$ length and polypropylene fiber $50 \mathrm{~mm}$ lenght), using as reference a plain concrete with $5 \mathrm{MPa}$ flexural strength.

More exactly, the study presents the change in compressive and flexural strength, shrinkage, thermal expansion factor, elastic modulus and Poisson`s ratio over fiber type and dosage.

For the highest performance concrete ( $7 \mathrm{MPa}$ flexural strength), it has been made a study using two methods for rigid airport pavements design (general method and optimized method), and one method for evaluation of bearing strength (ACN - PCN method), which is compared to a plain $5 \mathrm{MPa}$ concrete. Furthermore, the decrease in the slab's thickness proportionally to the growth of the flexural strength is emphasized by evaluating the slab's height for a high performance $9 \mathrm{MPa}$ concrete using both design methods.

Keywords: concrete, fiber, FRC, runway, design

\section{INTRODUCTION}

The airport pavement is the durable surface meant to sustain airplane traffic. It consists in a superimposed structure, each layer made of different materials, with different characteristics but, when put together, they give strength to the whole assembly.

The pavement which has Portland cement concrete as surface is named rigid pavement. It consists in concrete slabs divided by longitudinal and transversal cross-cut joints, whose thickness depends on the type of loads that it needs to sustain.

The specific feature that define the Portland cement concrete for roads and airport pavements is flexural strength, defined by NE014 and EN 13877 $1: 2013[1,2]$.

According to [1] cement concrete for pavements are divided according to their minimum characteristic flexural strength into 4 grades: BcR 3.5, BcR 4.0, BcR 4.5 and BcR 5.0.

Yet, [2] specifies concrete grades with up to $10 \mathrm{MPa}$ characteristic flexural strength.

A cause that induces large compressive and tensile stress and is mostly neglected, is due to temperature [3]. This has a bad influence on the behavior of the pavement and can lead to degradation of the surface and sometimes to dislocation of the entire row of slabs above the sub base layer [4].

In the concrete slabs submitted to daily temperature variation appears tensile or compression strains. They appear because of the subgrade's opposing friction forces and, sometimes, even because of the nearby slabs that oppose to 
free expansion or shrinkage produced by temperature gradient and humidity (concrete's shrinkage determine the appearance of tensile stress due to the friction forces of the subgrade to slab`s shrinkage tendency; contrariwise, concrete's expansions determine the appearance of compression stress due to the resisting forces of both the nearby slabs and the subgrade to slab`s expansion tendency) [4].

Also, it should be remembered that, following the hardening concrete shrinkage, it comes out a drop in tensile strength because of micro cracks.

One of the possibilities that exists in order to counteract the negative effects of the tensile stress, is the reinforcement of concrete either with classic steel bars/meshes or with fibers.

Worldwide, American Concrete Institute (ACI) [5] specifies the steel fibers and synthetic fibers among types used for fiber reinforced concrete.

In Europe, ERMCO - European Ready Mixed Concrete Organisation has developed the "Guidance to fiber concrete" [6] which particularizes properties, specifications and practice of fiber reinforced concrete.

Nationally, there are two types of fiber produced and used for reinforced concrete: steel and polypropylene fibers. These types of fibers were used in the following experimental study.

\section{MATERIALS AND METHODS}

Four different types of fiber were used:

- Hooked steel fiber, $50 \mathrm{~mm}$ lenght

- Hooked steel fiber, $30 \mathrm{~mm}$ lenght

- Crimped steel fiber, $30 \mathrm{~mm}$ lenght

- Polypropylene fiber, $50 \mathrm{~mm}$ length

Also, for $50 \mathrm{~mm}$ lenght hooked steel fibers, 3 different percentages of fiber were used:

$\bullet 0,5 \%$ of the concrete volume

$-1,0 \%$ of the concrete volume

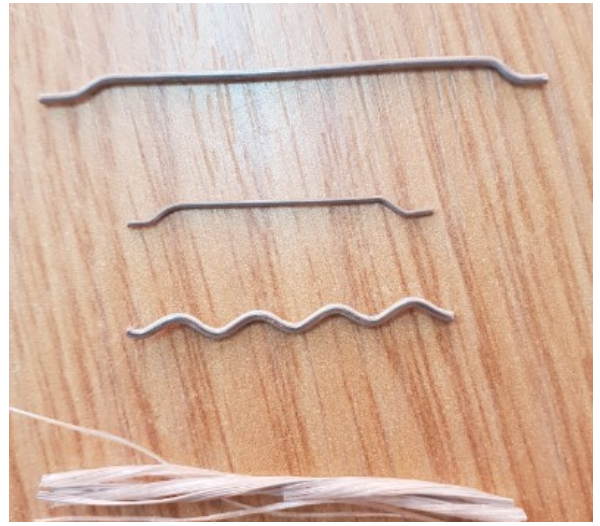

Figure 1. Fiber types

$\bullet 1,5 \%$ of the concrete volume

Density, elasticity modulus and tensile strength as declared by manufacturers are presented in table 1 . 
ROMANIAN JOURNAL

OF TRANSPORT INFRASTRUCTURE

Mihai DICU, Andreea MATEI, Constantin Dorinel VOINIȚCHI

Study of the influence of fibres type and dosage on properties of concrete for airport pavements

Table 1. Physical and mechanical properties of fibres

\begin{tabular}{|c|c|c|c|}
\hline Fibers type & $\begin{array}{c}\text { Density } \\
\left(\mathrm{g} / \mathrm{cm}^{3}\right)\end{array}$ & $\begin{array}{l}\text { Elasticity } \\
\text { modulus }(\mathrm{GPa})\end{array}$ & $\begin{array}{l}\text { Tensile } \\
\text { strength }(\mathrm{MPa})\end{array}$ \\
\hline $\begin{array}{c}\text { Hooked steel fiber, } \\
50 \mathrm{~mm} \text { lenght }\end{array}$ & 7.85 & 200 & 1100 \\
\hline $\begin{array}{c}\text { Hooked steel fiber, } \\
30 \mathrm{~mm} \text { lenght }\end{array}$ & 7.85 & 200 & 1100 \\
\hline $\begin{array}{c}\text { Crimped steel fiber, } \\
30 \mathrm{~mm} \text { lenght }\end{array}$ & 7.85 & 200 & 1100 \\
\hline $\begin{array}{c}\text { Polypropylene fiber, } \\
50 \mathrm{~mm} \text { lenght }\end{array}$ & 0.91 & 6 & 550 \\
\hline
\end{tabular}

The cement used for the mixes is a plain Portland cement type I 42,5R. The actual compressive strength of the cement, determined according EN 196-1 [7] was 43,5 MPa.

The aggregates used in concrete are natural sand $0 / 4$ and crushed stone divided into 4/8,8/16 and 16/25 aggregate sizes according to Romanian Norm NE014 - 02 [1].

Also, there were used plasticizer admixture (MasterGlenium $115-0,8 \%$ of the cement dosage) and air entraining admixture (MasterAir $9060-0,1 \%$ of the cement dosage).

For all concrete mixes, there was used a basic composition. Mixing proportions are according to [1] and they are presented in table 2 .

Using a drum mixer machine, aggregates and cement were mixed first for 1 minute. Then, the water was added and mixed again for another minute. Lastly, the admixures were added and the mixing continued for 2 minutes.

Table 2. Dosage of components

\begin{tabular}{|c|c|c|c|c|c|c|c|}
\hline $\begin{array}{c}\text { Cement } \\
\left(\mathrm{kg} / \mathrm{m}^{3}\right)\end{array}$ & $\begin{array}{c}\text { Water } \\
\left(\mathrm{kg} / \mathrm{m}^{3}\right)\end{array}$ & $\begin{array}{c}\text { Master } \\
\text { Glenium } \\
115 \\
\left(\mathrm{~kg} / \mathrm{m}^{3}\right)\end{array}$ & $\begin{array}{c}\text { MasterAir } \\
9060 \\
\left(\mathrm{~kg} / \mathrm{m}^{3}\right)\end{array}$ & $\begin{array}{c}0 / 4 \\
\left(\mathrm{~kg} / \mathrm{m}^{3}\right)\end{array}$ & $\begin{array}{c}4 / 8 \\
\left(\mathrm{~kg} / \mathrm{m}^{3}\right)\end{array}$ & $\begin{array}{c}8 / 16 \\
\left(\mathrm{~kg} / \mathrm{m}^{3}\right)\end{array}$ & $\begin{array}{c}16 / 32 \\
\left(\mathrm{~kg} / \mathrm{m}^{3}\right)\end{array}$ \\
\hline 350 & 147 & 3.5 & 0.35 & 660 & 268 & 410 & 517 \\
\hline
\end{tabular}

For fiber reinforced concrete, steel and polypropylene fibers were added in the basic concrete mix, using as well a drum mixer machine.

Fresh concrete properties - density, slump and air content were determined according to SR EN 12350 [8] and they are presented in table 3. 
ROMANIAN JOURNAL

OF TRANSPORT INFRASTRUCTURE

Mihai DICU, Andreea MATEI, Constantin Dorinel VOINIȚCHI

Study of the influence of fibres type and dosage on properties of concrete for airport pavements

Table 3. Fresh concrete porperties

\begin{tabular}{|c|c|c|c|c|c|c|}
\hline $\begin{array}{c}\text { Sample } \\
\text { code }\end{array}$ & Fibers type & $\begin{array}{c}\text { Fibers } \\
\text { dosage } \\
\left(\mathrm{kg} / \mathrm{m}^{3}\right)\end{array}$ & $\begin{array}{c}\text { Density } \\
\left(\mathrm{kg} / \mathrm{m}^{3}\right)\end{array}$ & $\begin{array}{c}\text { Slump } \\
(\mathrm{mm})\end{array}$ & $\begin{array}{c}\text { Air } \\
\text { content } \\
(\%)\end{array}$ & Observations \\
\hline Ax-R & - & 0 & 2360 & 40 & 3.6 & - \\
\hline Af-x & $\begin{array}{c}\text { hooked steel } \\
\text { fiber, 50mm }\end{array}$ & 40 & 2380 & 30 & 3.7 & - \\
\hline Af $_{\text {I-X }}$ & $\begin{array}{c}\text { hooked steel } \\
\text { fiber, 50mm }\end{array}$ & 80 & 2410 & 20 & 3.6 & - \\
\hline AFC-x & $\begin{array}{c}\text { hooked steel } \\
\text { fiber, 50mm }\end{array}$ & 120 & 2440 & 20 & 3.5 & - \\
\hline $\begin{array}{c}\text { AFCM- } \\
\text { X }\end{array}$ & $\begin{array}{c}\text { hooked steel } \\
\text { fiber, 30mm }\end{array}$ & 80 & 2410 & 20 & 3.6 & - \\
\hline AFO-x & $\begin{array}{l}\text { crimped steel } \\
\text { fiber, 30 mm }\end{array}$ & 80 & 2410 & 20 & 3.7 & - \\
\hline AFP-x & $\begin{array}{c}\text { polypropylene } \\
\text { fiber, 50 mm }\end{array}$ & 9 & 2340 & 10 & 3.8 & - \\
\hline ARC-1 & - & 0 & 2360 & 40 & 3.6 & $\begin{array}{c}\text { Shrinkage } \\
\text { reducing } \\
\text { admixture }\end{array}$ \\
\hline
\end{tabular}

Basic concrete and FRC samples were made using a vibrating table, using the following molds:

$-100 \times 100 \times 500 \mathrm{~mm}$ prisms for determining flexural strength (3 samples) and measuring thermal expansion coefficient (1) and shrinkage (1);

- cylinders with $150 \mathrm{~mm}$ diameter and $300 \mathrm{~mm}$ height for determining elasticity modulus and Poisson ration (1)

$-100 \mathrm{~mm}$ cubes for compressive strength determination (3).

The samples were removed from the mold after 24 hours and they were kept in water until 28 days according to EN $12390[9,10]$, except for the shrinkage test specimens. They were pulled out from water at 7 days and then kept in air at $20^{\circ} \mathrm{C}$ and $65 \% \mathrm{RH}$ according to Romanian Standard SR 2833 2009 [11].

The flexural strength was determined according EN 12390 - 5:2001 [9] using $300 \mathrm{~mm}$ distance between lower rollers of and $100 \mathrm{~mm}$ distance between upper rollers.

The compressive strength was determined according to EN 12390 3:2009 [10] using a Controls test machine. 
Thermal expansion coefficient was determined by measuring the change in length between samples kept in water at $21^{\circ} \mathrm{C}$ and the same samples kept at $81^{\circ} \mathrm{C}$.

The axial shrinkage of hardened concrete was determined according to SR $2833-2009$ [11].

The samples are set above some supports, above a sodium nitrite saturated solution $\left(\mathrm{NaNO}_{2}\right)$ up to 28 days, measuring their length and weight change every 7 days. The sodium nitrite saturated solution ensures about $65-$ $70 \%$ balanced humidity.

Elastic modulus and Poisson ratio were determined according to EN $12390-13: 2014$ [12]. The testing method consists in 5 loading cycles starting from $2 \%$ and going up to $35 \%$ of compressive strength using a compressive test machine for the load appliance, two compressometers for measuring the longitudinal strain and a strain gauge for measuring the transverse stress. The test specimen is a cylinder with $300 \mathrm{~mm}$ height and $150 \mathrm{~mm}$ diameter.

\section{RESULTS AND DISCUSSIONS}

Compressive strength of the reference concrete exceeded $45 \mathrm{~N} / \mathrm{mm}^{2}$, value imposed by current standards for BcR 5.0 [1]. The best compressive strength was obtained for $40 \mathrm{~kg} / \mathrm{mc}$ hooked steel fiber (see figure 2.a). Increasing the fibers dosage will result in decreasing the compressive strength. Yet, compared to reference concrete, the increment for the optimum dosage was low $-9 \%$. Data is in accordance with [13] and show no significant influence of fibers on compressive strength of FRC.

Regarding fiber types, one can see in figure $2 . b$ that the best performance was obtained for $50 \mathrm{~mm}$ hooked steel fiber (fiber length represents approximately two diameters of maximum grain), while the polypropylene fiber's strength registered a slight decrease, according to literature data [13].

The same results were accomplished by Federal Aviation Administration on a research about polypropylene fiber reinforced concrete [14] related to steel fiber reinforced concrete, meaning that the compressive strength does not show a large improvement due to the addition of any fiber type (steel ori polypropylene fiber). 
ROMANIAN JOURNAL

OF TRANSPORT INFRASTRUCTURE

Mihai DICU, Andreea MATEI, Constantin Dorinel VOINIȚCHI

Study of the influence of fibres type and dosage on properties of concrete for airport pavements
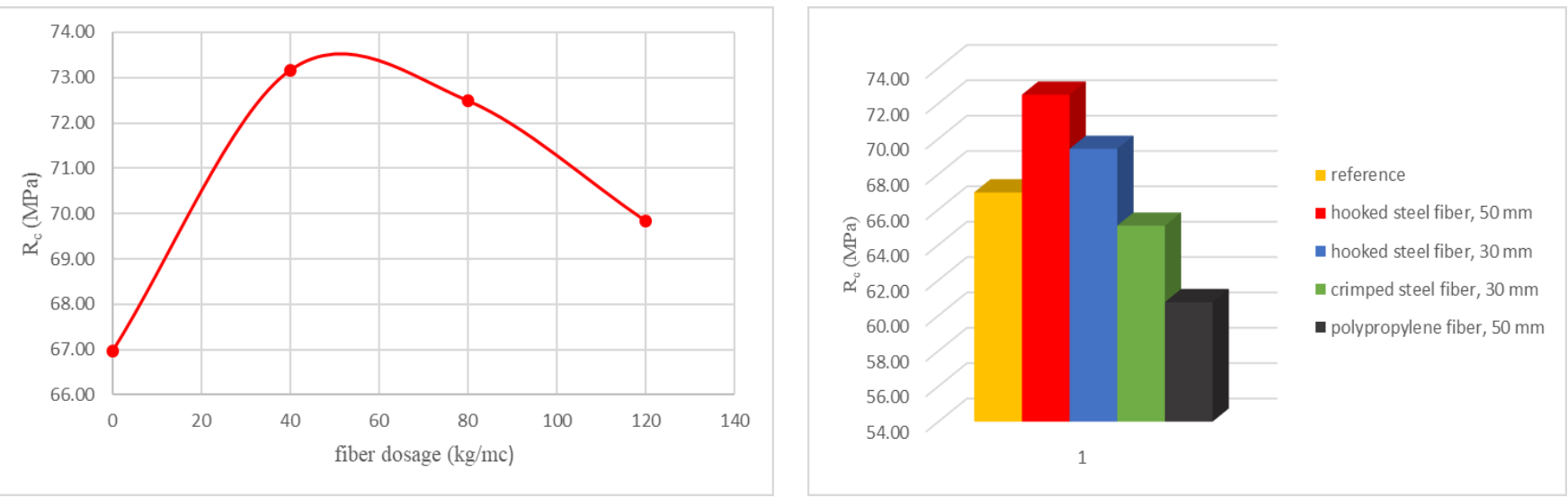

Figure 2. a - Compressive strength vs fiber dosage,

b- Compressive strength vs fiber type

Flexural strenght exceeded $5,5 \mathrm{~N} / \mathrm{mm}^{2}$ for the reference concrete as imposed by [1] for BcR 5.0. The best flexural strength was obtained for 80 $\mathrm{kg} / \mathrm{mc}$ hooked steel fiber (see figure 3). Increasing the dosage will result in a small decreasing the strength. Regarding fiber types, one can see in figure 3 that the best performance was obtained for $50 \mathrm{~mm}$ hooked steel fiber, a $35 \%$ increase in flexural strength.

The FAA study [14] also states that the polypropylene fibers have moderate to no influence on flexural strength, while for the steel fibers the increase is up to $50 \%$ or more.
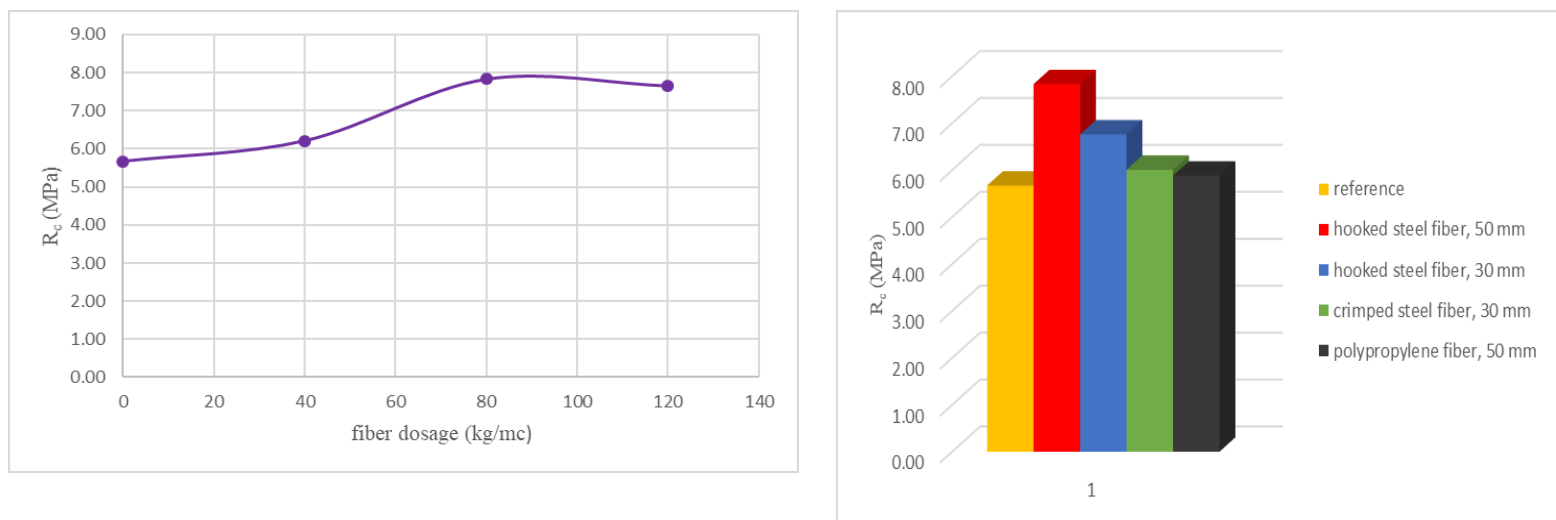

Figure 3. a - Flexural strength vs fiber dosage,

b- Flexural strength vs fiber type

The longitudinal elastic modulus for reference concrete exceeded 30 $000 \mathrm{MPa}$, the standard value used in design [15]. The best performance for longitudinal elastic modulus was obtained for $120 \mathrm{~kg} / \mathrm{m}^{3}$ dosage (see figure 4), 
ROMANIAN JOURNAL

OF TRANSPORT INFRASTRUCTURE

but is not significant, as in literature [13]. Regarding fiber types, there were improvements in the longitudinal elastic modulus, though, for the polypropylene fiber there was a decrease of $12.2 \%$. The best performance for was obtained for $50 \mathrm{~mm}$ hooked steel fiber.
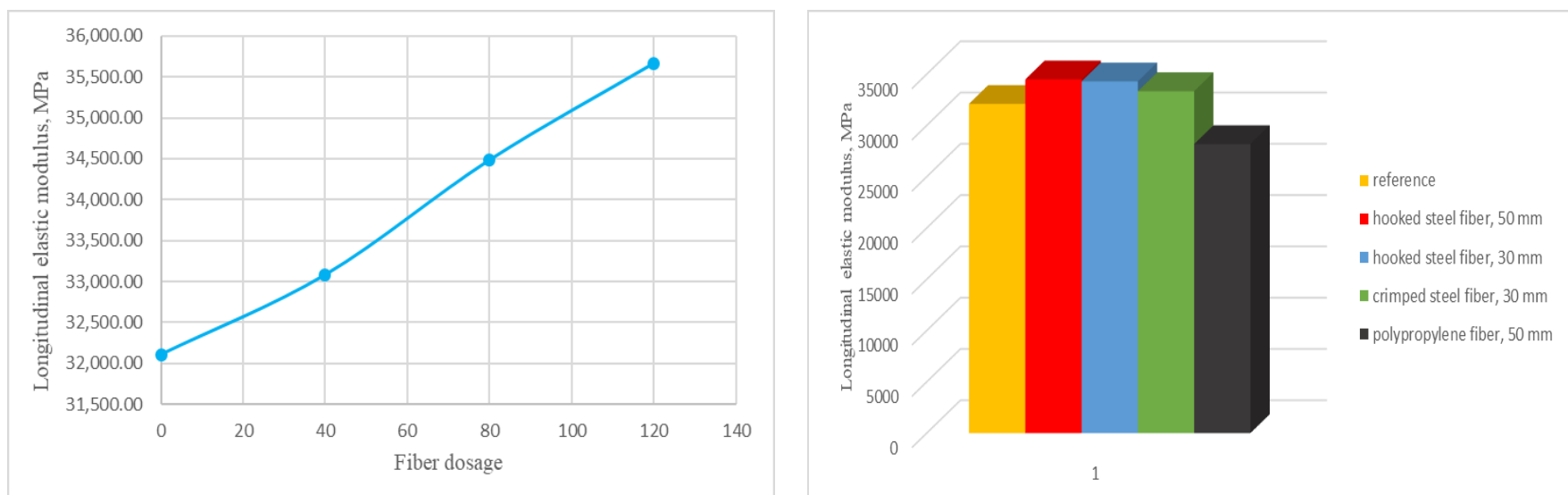

Figure 4. a - Longitudinal elastic modulus vs fiber dosage,

b - Longitudinal elastic modulus vs fiber type

The transverse elastic modulus decreased when the fiber dosage was increased (see figure 5).
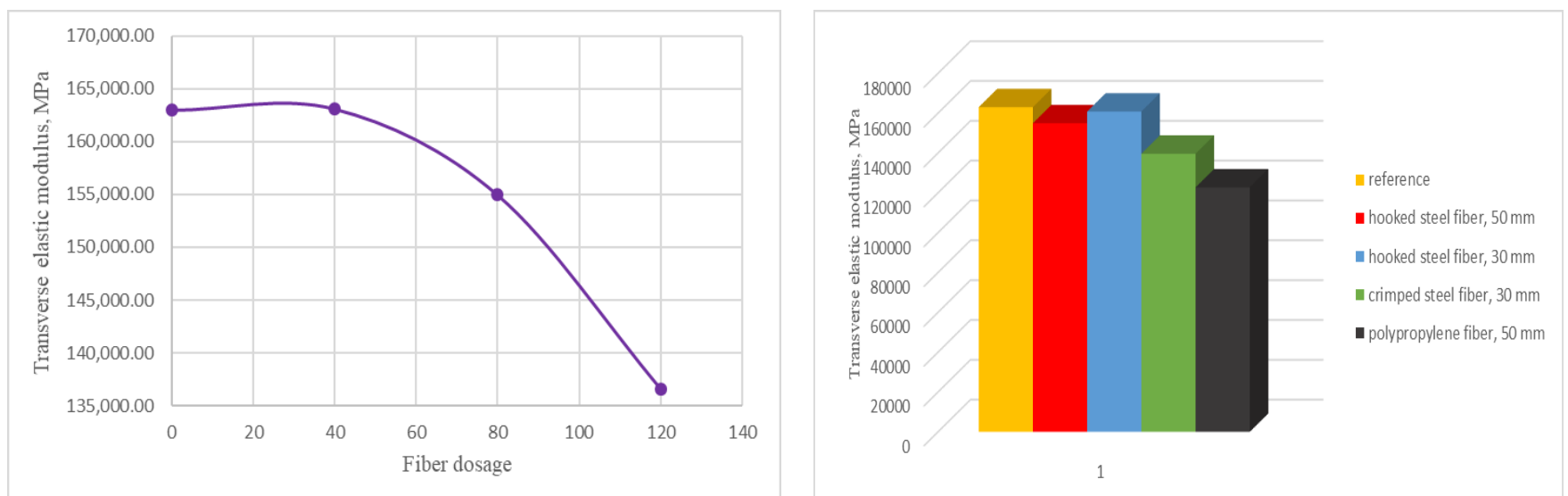

Figure 5. a - Transversal elastic modulus vs fiber dosage, b- Transversal elastic modulus vs fiber type

The increase in Poisson's ratio is increasing with fibers dosage for crimped steel fiber (see figure 6a). Crimped fibers seem to have the greatest influence, followed by polypropylene fibers which showed an increase of Poisson ratio of $16 \%$. 
ROMANIAN JOURNAL

OF TRANSPORT INFRASTRUCTURE

Mihai DICU, Andreea MATEI, Constantin Dorinel VOINIȚCHI

Study of the influence of fibres type and dosage on properties of concrete for airport pavements
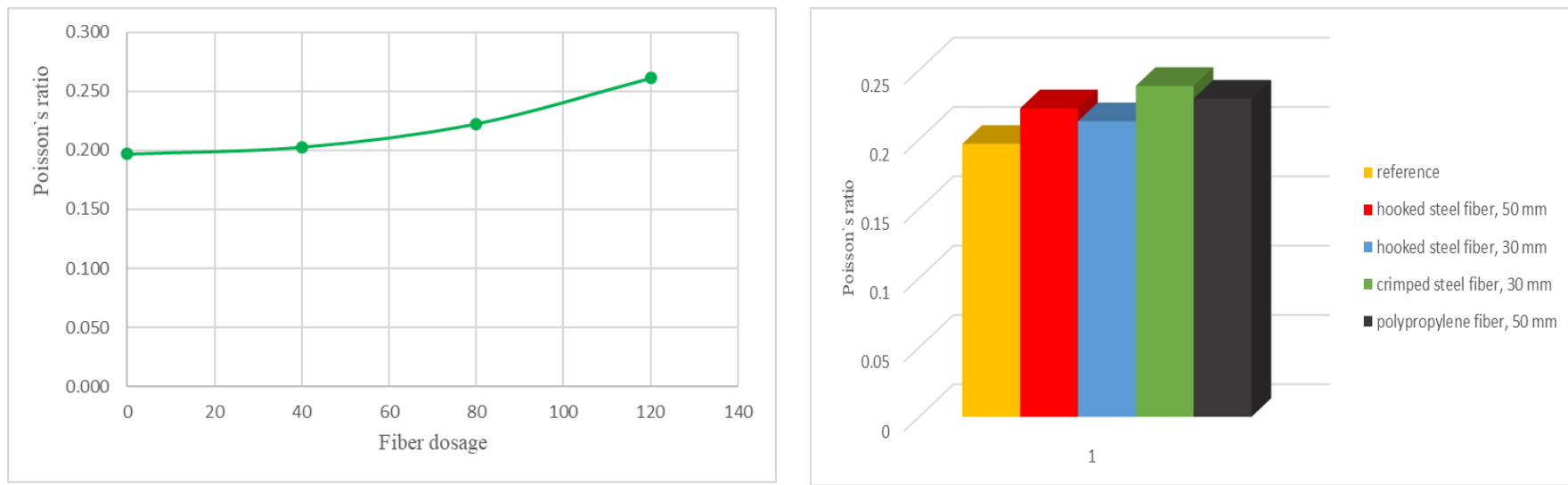

Figure 6. a - Poisson ratio vs fiber dosage,

b - Poisson ratio vs fiber type

Thermal expansion coefficient of samples showed that the effect of fibers type or dosage is not visible (it's value is $0,01 \mathrm{~mm} / \mathrm{m} \times{ }^{\circ} \mathrm{C}$ as for reference concrete), as expected. This can be explained by the small amount of fibers and that the values of thermal expansion coefficient for steel and concrete are very close.

Shrinkage values at 14, 21 and 28 days are presented in figure 7 for all compositions, showing no major difference even when using shrinkage reducers. All samples showed low shrinkage, around $0,2 \mathrm{~mm} / \mathrm{m}$, due to moderate cement dosage and $\mathrm{w} / \mathrm{c}$ ratio.

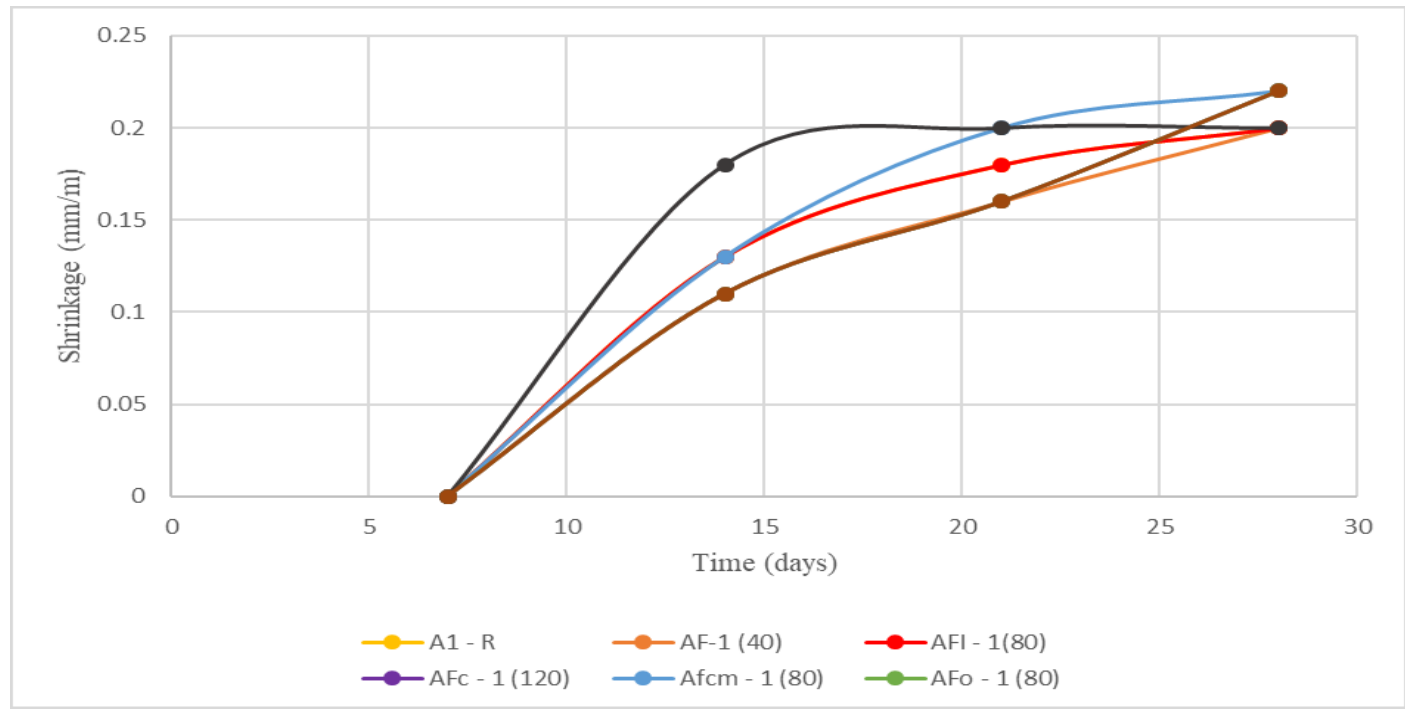

Figure 7. Shrinkage evolution over time 
Fiber's type or dosage does not affect shrinkage. In fact, these seems not to affect at all the concrete's contractions, but decrease their effects.

Shrinkage is provoked mainly by the mass loss as it can be seen in figure $8 \mathrm{a}, \mathrm{b}$. Sample`s shrinkage is basically proportional with the amount of water loss.
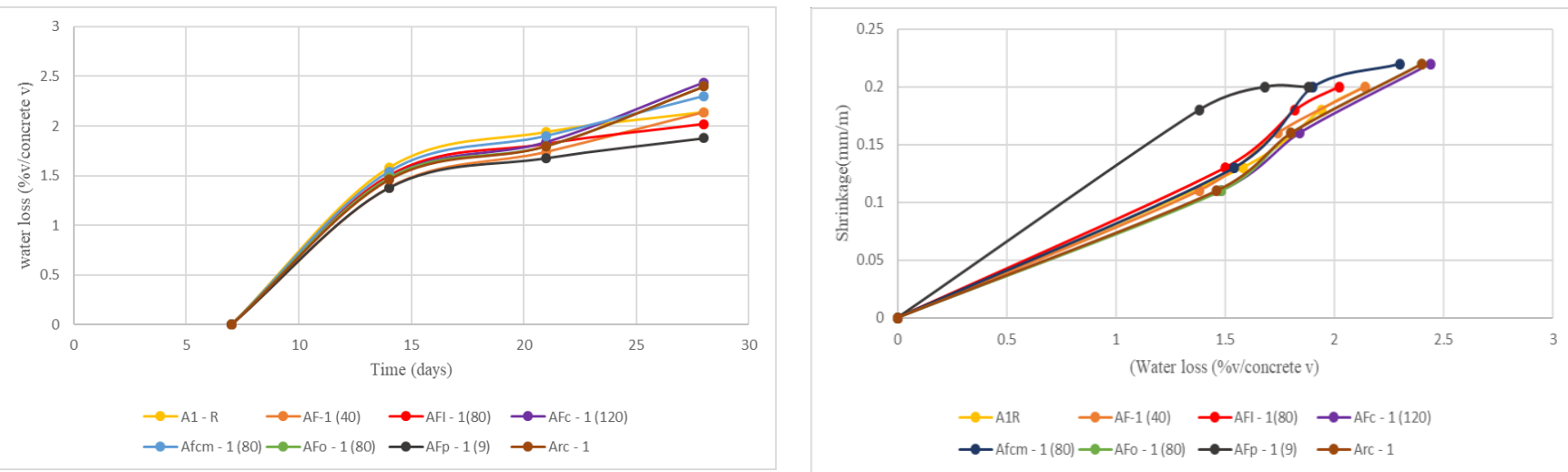

Figure 8. a - Change in mass loss over time, b - Shrinkage vs water loss

The size of the shrinkage is linear dependent regarding water loss, which emphasize the significance of curing the concrete.

The shrinkage reducing agent seems not to have any significant effects in this situation, the sample having same behavior with the others.

\section{STUDY ON SLAB DESIGN FOR RUNWAY PAVEMENTS}

The purpose of this study was to emphasizes the influence of fiber reinforced concrete for runway pavements as the decrease of the slab's thickness, compared to a plain 5MPa flexural strength mix.

Using three hypothetical airplanes, there were made all three verifications specified in NP034 - 99 [16] and NP044 - 2000 [17]:

- The general method: slab`s thickness was estimated for the most representative airplane for the airport - Airbus A340 - 300 X

- The optimized method: slab's thickness was evaluated for all the representative airplanes for the airport - Airbus A340 - 300 X, McDonnel Douglas DC 9 - 15 and Airbus A310 - 300

- The ACN - PCN method: for all three airplanes mentioned above, there were evaluated aircraft classification numbers compared to pavement 
classification number and, therefore, checked the bearing strength and the admissibility of the planes on the airport

Following the calculus for the general method, the slab's thickness for $5 \mathrm{MPa}$ plain mix was $47 \mathrm{~cm}$. It was ascertained that the slab's thickness is reduced by $23.40 \%$ if one uses $7 \mathrm{MPa}$ fiber reinforced concrete and by $40 \%$ if one uses 9MPa fiber reinforced concrete, decreasing from $47 \mathrm{~cm}$ to $28 \mathrm{~cm}$.

Following the calculus for the optimized method, the slab`s thickness for $5 \mathrm{MPa}$ plain mix was $51 \mathrm{~cm}$. For a $7 \mathrm{MPa}$ fiber reinforced concrete, the thickness decreased from $51 \mathrm{~cm}$ to $39 \mathrm{~cm}$. However, the $39 \mathrm{~cm}$ value was too high because the equivalent traffic was much lower than 36500 moves and one should reduce this value on calculus until it reaches an approximate but shorter number of moves.

The evaluation of bearing strength was satisfying, all the airplanes are supposed to be accepted on the airport with no restrictions.

\section{CONCLUSIONS}

In conclusion, there was obtained and characterized in laboratory a high performance reinforced concrete with low shinkage and strongly increased characteristics, using a properly dosage and type of fiber.

The design calculus proved that the pavement thickness can be reduced up to $40 \%$ using fiber reinforced concrete.

\section{REFERENCES}

[1] NE 014 - "Norms for execution of Portland cement concrete pavements in fixed or sliding formworks"

[2] EN 13877-1:2013 - “Concrete pavements. Part 1: Materials”

[3] Al-Qadi, Scarpas \& Loizos (eds) - "Pavement Cracking"-Taylor \& Francis Group, London, ISBN 978-0-415-47575-4, 2008

[4] STAN JERCAN - “Concrete roads", Corvin Publishing House, 2002

[5] AMERICAN CONCRETE INSTITUTE (ACI) - "State-Of-The-Art Report on Fiber Reinforced Concrete”, $\mathbf{2 0 0 2}$ 


\section{ROMANIAN JOURNAL \\ OF TRANSPORT INFRASTRUCTURE}

Mihai DICU, Andreea MATEI, Constantin Dorinel VOINIȚCHI

Study of the influence of fibres type and dosage on properties of concrete for airport pavements

"Guidance to fiber concrete - Properties, Specification and Practice in Europe", sept. 2002

[7] EN 196-1 - "Methods of testing cement. Part 1: determination of strength"

[8] SR EN 12350 - 7 - "Testing fresh concrete. Part 7: Air content - Pressure methods"

[9] EN $12390-5: 2001-$ "Testing hardened concrete. Part 5: Flexural strength of test specimens"

[10] EN 12390 - 3:2009 - "Testing hardened concrete. Part 3: Compressive strength of test specimens"

[11] SR 2833 - 2001 - "Testing on concretes. Determination of the axial shrinkage of hardened concrete."

[12] EN 12390 - 13:2014 - "Testing hardened concrete. Part 13: Determination of secant modulus of elasticity in compression”

[13] Technical manual MACCAFERRY - "Fibers as structural element for the reinforcement of concrete"

[14] DOT - FAA - "Polypropylene Fibers in Portland Cement Concrete Pavements", DOT/FAA/RD - 92/9, 1992

[15] Buletin Tehnic Rutier 2:2002

[16] NP $034-99$ - "Normative for design of rigid pavements for airports"

[17] NE $044-2000$ - "Normative for evaluating the pavement's bearing strength for airports" 